Special Issue: Agricultural Productivity and Sustainability Improvement in Tropical Region

\title{
Curcuma xanthorriza Roxb. as Feed Additive on the Carcass and Fat Weight Percentage, Meat Nutrient, and Nutrient Digestibility of Super Kampong Chicken
}

\author{
Wahyu Widodo,*, Imbang Dwi Rahayu², Adi Sutanto ${ }^{3}$, Apriliana Devi Anggraini ${ }^{4}$, Harum Sahara ${ }^{4}$, \\ Sara Safitri ${ }^{4}$ and Abubakar Yaro ${ }^{5,6}$
}

${ }^{1}$ Nutrition Laboratory, Faculty of Agriculture and Animal Science, University of Mubammadiyah Malang, Jl. Raya Tlogomas No 246, Malang 65144 Indonesia; ${ }^{2}$ Reproduction Laboratory, University of Muhammadiyah Malang, Malang, Indonesia; ${ }^{3}$ Social Economic Laboratory, University of Mubammadiyah Malang, Malang, Indonesia; ${ }^{4}$ Department of Animal Science, Faculty of Agriculture and Animal Science, University of Mubammadiyah Malang, Malang, Indonesia; ${ }^{5}$ Strathclyde Institute of Pharmacy and Biomedical Sciences (SIPBS), University of Strathclyde, SPBBS, 161 Cathedral St, Glasgow G4 ORE, Scotland, United Kingdom; ${ }^{6} \mathrm{Dr}$ Yaro Laboratory and AHRO Institute of Health Sciences and Research, 272 Bath Street, Glasgow, Scotland, G2 4JR, United Kingdom.

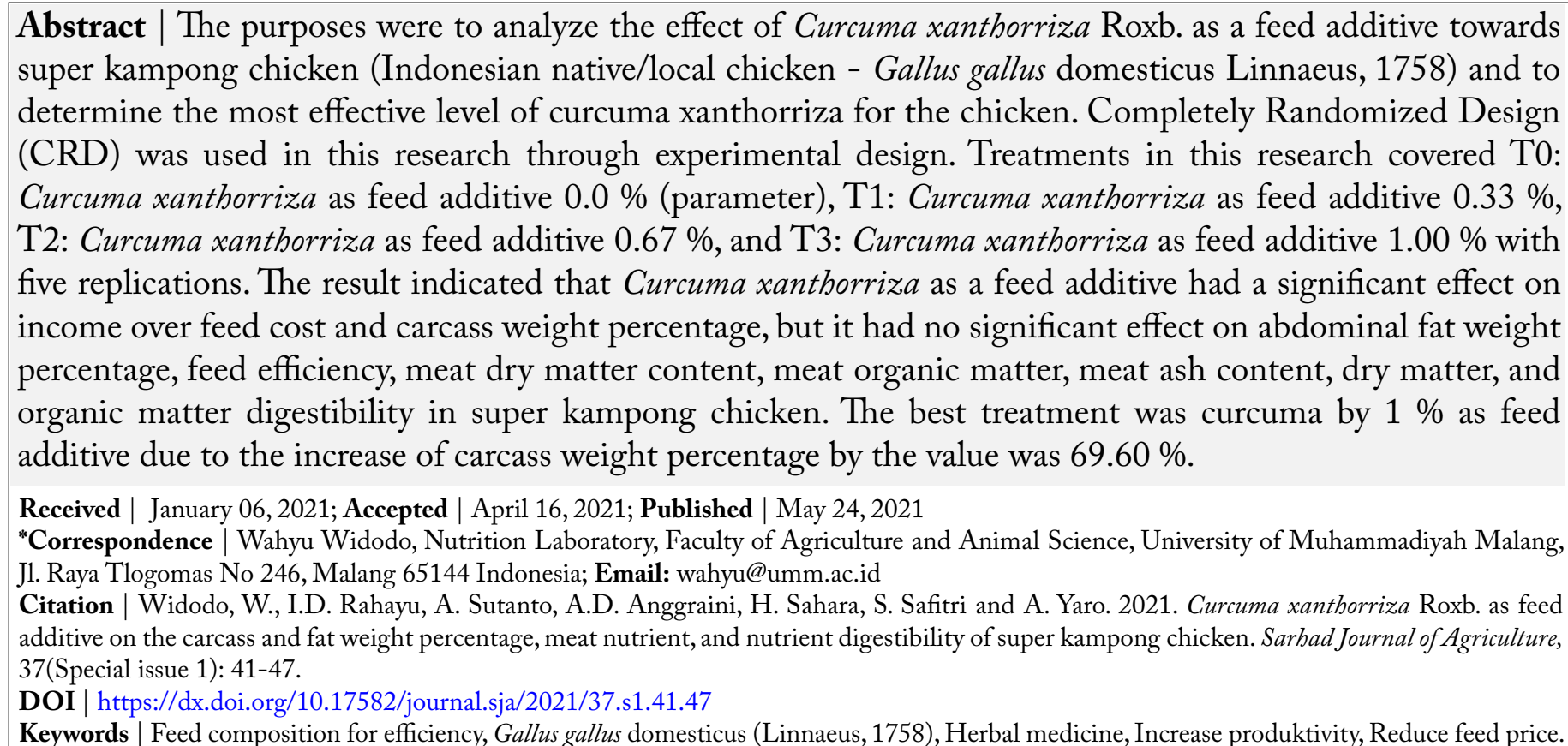

\section{Introduction}

$\mathrm{R}$ aising livestock is important to sustain food production, and it is especially key in poultry farming due to its being one of the most-consumed products. Attempts to provide the best feed formula have been around from time to time, involving the vast selection of compositions, to ensure optimal supplies. Lately, local poultry farmers have been more interested in going back to nature to provide healthier feed for their cattle without spending too much while, at the same time, maintaining their farms' outputs both qualitatively and quantitatively. The use of feed additives is therefore directed to herbal plants, as they are quite easy to locate and publicly accepted to give medicinal effects to both human and 
animal - zingiber [Zingiber zerumbet (L.) Roscoe. ex $\mathrm{Sm}$ ], curcuma (Curcuma xanthorriza Roxb.), galangal [Alpinia galangal (L.) Wild.], and turmeric (Curcuma longa L.) are some which have been studied for this purpose (Rahayu et al., 2019a, 2019b; Widodo et al., 2019). The extract of zerumbet by $95 \%$ ethanol and $10 \%$ concentration have the best antibacterial activity against Salmonella enteritidis. Whereas, Salmonella typhimurium is effectively inhibited by extracts with $45 \%$ ethanol and $7.5 \%$ extract concentration (Rahayu et al., 2019b). Studying specifically a species of local poultry called "ayam kampung" (Indonesian native/local chicken - Gallus gallus domesticus Linnaeus, 1758), Widodo et al. (2018) stated that adding $Z$. zerumbet in the feed was not significant $(\mathrm{P}>0.05)$ in improving crude fiber digestibility, protein biological value, and nitrogen retention; yet, it was effective $(P<0.05)$ in fat digestibility.

Curcuma xanthorriza Roxb, or locally popular in Java, Indonesia as "temulawak", is high in curcumin and essential oil contents (Widodo et al., 2019; Rahayu et al., 2019a, 2019b). According to Dermawaty (2015) and Lee et al. (2008) curcuminoids in C. xanthorriza have antibacterial, anti-cancer, anti-tumor, and antioxidant agents. C. xanthorriza also contains essential oils - such as limonin - which can kill microbes, while flavonoid content can cure inflammation (Emadi and Kermanshahi, 2007). Curcumin, according to Rahim et al. (2014) and Ghalandarlaki et al. (2014), can shorten the acid cycle in the stomach and accelerate blood sugar release from body cells. The low level of sugar in the blood triggers a faster cycle of hunger in chickens, which helps reduce stress risk (Devaraj et al., 2010; Salas et al., 2012). Stimulating hunger in chickens should spur the efficiency of chicken feeding, and they can reach a higher percentage of carcass weight than general maintenance time on that account. If such a scenario works, income over feed cost should be optimized (Afzal and Khan, 2017).

C. xanthorriza supplementary feed is effective towards "ayam kampung super" (Indonesian native/local chicken - Gallus gallus domesticus Linnaeus, 1758), is the main parameter to measure feed ability. Akhardiato (2010) stated that giving $C$. xanthorriza in the feed had no significant effect to dry matter digestibility by the value about $6.28 \%$ to $71.31 \%$ and organic matter by the value about $71.51 \%$ to $74.31 \%$. Therefore, it is necessary to analyze whether $C$. xanthorriza is influential in chicken meat nutrition and nutrient digestibility and, if it is, how much of it should be the most advantageous. This study conducted to determine information on the aforementioned points.

\section{Materials and Methods}

This research was conducted in January to March 2019, taking place at the closed house and the laboratory of Animal Science, Faculty of Agriculture and Animal Science, the University of Muhammadiyah Malang in Tegalgondo Village, Karangploso District, Malang Regency. The research materials were 100 DOCs (Day Old Chicks) of super kampong chicken from the hatchery plant in Tulungagung district. Transportation of the chicks from Tulungagung district to Malang city where research conducted was in the good condition. Commercial feed (Broiler Starter AB1 Crumble and Broiler Finisher AB2 Pellet from JAPFA) was as the main feed, and C. xanthorriza was mixed in the feed. The variables were collected at the age of the chickens at $8 \mathrm{wk}$. Nine variables used in this research to measure up the effectiveness of feed (as suggested in Widodo, 2014) were income over feed cost (IOFC), carcass weight percentage, feed efficiency, abdominal fat weight percentage, meat dry matter content, meat organic matter content, meat ash content, dry matter digestibility, and organic matter digestibility. The meat dry matter is heated in an oven at a temperature of $105{ }^{\circ} \mathrm{C}$ with continuous heating until the weight is constant. The ash content can be determined by entering the material into the furnace. The organic matter is determined by dry matter less ash content. All three variables use percentage units IOFC is income over feed costs, calculated with equation (1)

IOFC (IDR) $=$ Total sales (IDR) - Feed cost (IDR) ......... (1)

The percentage of carcass weight is calculated by cquation (2)

$$
\% \text { carcass weight }=\frac{\text { Weight of carcass }}{\text { The final weight }} \times 100 \ldots \ldots \ldots(2)
$$

The percentage of abdominal fat weight is calculated by equation (3)

$$
\text { Abdominal fat weight }=\frac{\text { Fat in abdominal }}{\text { The final weight }} \times 100 \ldots \ldots \text { (3) }
$$

The digestibility of dry matter (DM), be measured by equation (4)

Digestibility of DM $=\frac{(\text { DM consumption }- \text { DM excreta })}{\text { DM consumption }} \times 100 \ldots \ldots$ (4) 
Table 1: Effects of adding C. xanthorriza in the feed on the carcass and fat weight percentage, meat nutrient, and nutrient digestibility of super kampong chicken.

\begin{tabular}{lcccc} 
Variable & \multicolumn{3}{c}{ Treatments } \\
& T0 (0\%) & T1 (0.33\%) & T2 (0.67\%) & T3 (1\%) \\
Feed efficiency & $33.21 \pm 0.16^{\mathrm{a}}$ & $33.13 \pm 0.21^{\mathrm{a}}$ & $32.37 \pm 0.44^{\mathrm{a}}$ & $31.08 \pm 0.14^{\mathrm{a}}$ \\
IOFC (IDR) & $15208.51 \pm 1475.49^{\mathrm{c}}$ & $13686.22 \pm 971.58^{\mathrm{bc}}$ & $12057.49 \pm 1547.25^{\mathrm{b}}$ & $10194.314 \pm 1009.17^{\mathrm{a}}$ \\
Carcass weight percentage (\%) & $54.00 \pm 4.18^{\mathrm{a}}$ & $58.80 \pm 4.02^{\mathrm{b}}$ & $61.20 \pm 2.59^{\mathrm{bc}}$ & $69.60 \pm 3.78^{\mathrm{c}}$ \\
\hline Abdominal fat weight percentage (\%) & $1.09 \pm 0.46^{\mathrm{a}}$ & $0.84 \pm 0.10^{\mathrm{a}}$ & $1.39 \pm 0.31^{\mathrm{a}}$ & $1.44 \pm 0.67^{\mathrm{a}}$ \\
Meat dry matter content (\%) & $93.72 \pm 0.96^{\mathrm{a}}$ & $93.56 \pm 1.67^{\mathrm{a}}$ & $92.33 \pm 1.38^{\mathrm{a}}$ & $92.76 \pm 1.23^{\mathrm{a}}$ \\
Meat organic matter content (\%) & $84.54 \pm 1.89^{\mathrm{a}}$ & $85.18 \pm 1.16^{\mathrm{a}}$ & $84.76 \pm 1.08^{\mathrm{a}}$ & $85.70 \pm 0.98^{\mathrm{a}}$ \\
Meat ash content (\%) & $15.46 \pm 1.89^{\mathrm{a}}$ & $14.82 \pm 1.16^{\mathrm{a}}$ & $15.24 \pm 1.08^{\mathrm{a}}$ & $14.30 \pm 0.98^{\mathrm{a}}$ \\
Dry matter digestibility (\%) & $77.28 \pm 4.44^{\mathrm{a}}$ & $76.07 \pm 1.95^{\mathrm{a}}$ & $77.19 \pm 3.19^{\mathrm{a}}$ & $75.23 \pm 3.61^{\mathrm{a}}$ \\
Organic matter digestibility (\%) & $63.01 \pm 2.97^{\mathrm{a}}$ & $62.25 \pm 1.23^{\mathrm{a}}$ & $63.07 \pm 2.11^{\mathrm{a}}$ & $61.70 \pm 2.16^{\mathrm{a}}$
\end{tabular}

The same letter in the same line shows no differences, while different letters indicate differences.

The digestibility of organic matter $(\mathrm{OM})$ can be measured by equation (5)

Digestibility of $\mathrm{OM}=\frac{(\mathrm{OM} \text { consumption }- \text { OM excreta })}{\text { OM consumption }} \times 100 \ldots \ldots(5)$

The research method employed in this study was the experimental designed on Completely Randomized Design (CRD) with five replications. The treatments were prepared by $C$. xanthorryza tubers were made into powder and mixed with the feed as: T0, C. xanthorriza as feed additive $0.0 \%$ (serving as the control); T1, C. xanthorriza as feed additive $0.33 \%$; T2, C. xanthorriza as feed additive $0.67 \%$, and T3, C. xanthorriza as feed additive $1.00 \%$.

The data were then analyzed using Variance Analysis (ANOVA), and the results were delivered following the Least Significant Difference (LSD).

\section{Results and Discussion}

The results of curcuma addition in the feed of the studied super kampong chicken came out with varying results as listed in Table 1.

Based on Table 1 that the IOFC and carcass weight percentage of super kampong chicken were significantly $(\mathrm{P}<0.01)$ affected by $C$. xanthorriza. On the other hand, the abdominal fat weight percentage, feed efficiency, meat dry matter content, meat organic matter content, meat ash content, dry matter digestibility, organic matter digestibility were non significantly affected by $C$. xanthorriza. Opposing trends between IOFC and carcass weight percentage appear in the LSD test. Regarding IOFC, the T3 result was significantly different from $\mathrm{T} 2, \mathrm{~T} 1$, and $\mathrm{T} 0$, while $\mathrm{T} 2$ was non-significantly different or similar to T1 but different from T0, and T1 was similar to T0. The best IOFC overall value was obtained by $\mathrm{T} 0$. As for carcass weight percentage, the T0 result was different from T1, T2, and T3, while T1 was similar to T2 but different from T3, and T2 was similar to T3. The best Carcass Weight Percentage overall value, therefore, goes to T3. It can be inferred from the description that although $C$. xanthorriza additive in feed does not increase the value of IOFC (which is regarded as cost waste in feed), it helps to optimize meat formation (which is potential to output growth). Due to the additive, T1, T2, T3 required higher costs than $\mathrm{T} 0$, and they were different from one another.

Sinurat et al. (2009) stated that feed consumption, feed price, body weight, and selling price were influential towards chicken's IOFC value, while Kalamkar (2012) revealed that the high price of feed could reduce farmers' income. Despite being able to produce a higher rate of body weight, the C. xanthorriza additive is not that efficient in other aspects. Yet, its involvement in a range of $0 \%$ to $1 \%$ does not add much to feed cost, which is in line with Choe et al. (2010)'s statement that herbal additives should not be a matter of concern in the feed price increase.

The best outcome regarding the variable of carcass weight percentage $(69.60 \%)$ was found in T3, which 
had comprised Cxanthorriza $1 \%$. This result is higher than the result from Akhardiato (2010) that stated the percentage of broiler carcass weight at $5 \mathrm{wk}$ of age varies from $56 \%$ to $66 \%$ of body weight. This proves that at the respective percentage, $C$. xanthorriza adding can increase the carcass weight optimally and, consequently, improve the performance of super kampong chicken.

C. xanthorriza rhizome contains active compounds including terpenoids, alkaloids, flavonoids, essential oils, phenols, and curcuminoids, which function as antimicrobials often used in traditional herbal remedies. Referring to Stoilova et al. (2007) curcumin, a polyphenolic compound derived from C. xanthorriza rhizome, was reported to have natural anti-oxidant functions and help to improve digestive tract conditions as well as to reduce cholesterol content by facilitating nutrient absorption, cholesterol degradation, and cholesterol elimination. Curcumin compounds stimulate a higher amount of dilute bile secretion, which is important to digestion. Should more enzymes be produced to digest starch and fat, more nutrients will be available to be absorbed by microvilli in the intestine (Jantan et al., 2012). However, the compounds are proven not capable of reaching the optimal target of organic matter level increase in super kampong chicken meat.

The presence of curcumin compounds stimulates the production of bile and facilitates the secretion of bile. In our study, the use of C. xanthorriza of $1 \%$ was more effective for accelerating the absorption of nutrients. In Sugiharto et al. (2017)'s research, giving turmeric to broiler by level $3 \%$ tended to increase bile production up to $6 \%$; it means that the higher the C.xanthorriza level is given, the lower the carcass weight percentage will be. The study of Suriya et al. (2012) about color and texture, finding that chicken fed with curcuma additives produces smoother meat chicken texture.

From Table 1 , the treatment of $C$. xanthorriza addition had given no significant effect $(\mathrm{P}>0.05)$ on feed efficiency, abdominal fat weight percentage, meat dry matter content, meat organic matter content, meat ash content, dry matter digestibility, and organic matter digestibility in super kampong chicken. The determining variable in the value of feed efficiency was feed consumption and body weight gain. Since the average feed consumption between treatments was only slightly different and the increase in body weight between treatments was nearly the same, the feed efficiency value was therefore almost the same; conclusively, the treatment did not bring significant effect. The feed consumed must be given as much as possible because the feed affects the weight gain. This is following the opinion of Chukwuji et al. (2006) stated that giving feed for chicken is important because of the basic needs that affect the body weight gain of chicken.

Based on Table 1, the average abdominal fat weight percentage between treatments in super kampong chicken was almost the same. This result is consistent with the study of Golla et al. (2014), stating that the addition of $C$. xanthorriza to feed with a level of $2 \%$ did not have a significant effect on the abdominal fat weight percentage. It is also under the opinion of Daneshyar et al. (2011) that the higher the level of $C$. xanthorriza added, the abdominal fat weight percentage would be the lower.

From Table 1, the addition of $C$. xanthorriza in the feed had no significant effect on the content of meat dry matter, meat organic matter, and meat ash of super kampong chicken. This shows that the average between treatments was almost the same, causing the C. xanthorriza adding to work less effectively. C. xanthorriza can accelerate gastric emptying so that hunger arises and, consequently, stimulate appetite ( $\mathrm{Yu}$ et al., 2012). However, from Table 1, we can know the curcumin and essential oils in the $C$. xanthorriza still cannot influence optimally to increase the content of dry matter, organic matter, and an ash content of super kampong chicken meat.

Based on Table 1, C. xanthorriza can improve meat quality but has not been able to increase the meat dry matter content, meat organic matter, and meat ash content. The results of this study were in line with Samadi et al. (2019) stated the addition of $Z$. zerumbet containing curcumin to the herbal mixture had no significant effect on the ash content of chicken meat. The addition of $Z$. zerumbet containing curcumin in the herbal mixture on the value of ash content in chicken meat was $5.84 \%$. Nutrient content in the feed given during maintenance was relatively the same so that each treatment was relatively the same effect on the meat ash content (Saili et al., 2019).

According to Table 1, the addition of C. xanthorriza 
in the feed did not significantly affect the dry matter digestibility and organic matter digestibility of super kampong chicken. This shows that the nutrient content in the feed, curcumin, and essential oils found in C. xanthorriza still may not optimize antibacterial function. The antibacterial mechanism reduces the bacterial population in the digestive tract of super kampong chicken so that the digestive tract organs are prevented from diseases caused by Escherichia coli (Patzko et al., 2012).

\section{Conclusions and Recommendations}

Curcuma xanthorriza as a feed additive has a significant effect on income over feed cost and carcass weight percentage, but it has no significant effects on abdominal fat weight percentage, feed efficiency, meat dry matter content, meat organic matter content, meat ash content, dry matter digestibility, and organic matter digestibility in super kampong chicken. The best treatment level should be $C$. xanthorriza by $1 \%$ as a feed additive. The recommendation is the chicken should be given $C$. xanthorriza as a feed additive by $1 \%$ due to the best percentage of carcass.

\section{Acknowledgments}

The authors wish to express their gratitude to the Ministry of Research and Technology and Higher Education of Indonesia for funding this research by PTUPT program no 6/E/KPT/2019. It is also thanks to the Directorate of Research and Community Services of Animal Science Department, Agriculture, and Animal Science Faculty, the University of Muhammadiyah Malang for the opportunity to carry out this research.

\section{Novelty Statement}

Research on Curcuma xanthorriza as a feed additive to super kampong chickens is never conducted, most research has been done in the broiler. The addition of C. xanthorriza in feed can improve meat tissue, which shows the optimization of protein in meat formation and ultimately increases carcass weight in the super kampong chicken.

\section{Author's Contribution}

WW, IDR and AS conceptualized and designed the study, elaborated the intellectual content, performed literature search, data acquisition, data analysis, statistical analysis, and manuscript preparation. ADA, HS and SS defined the intellectual content, carried out literature search, experimental studies, and manuscript review. WW and AY performed manuscript editing and guarantor.

\section{Conflict of interest}

The authors declare that there is no conflict of interests regarding the publication of this article

\section{References}

Akhardiato, S. 2010. The effect of giving temban, biovet and biolacta probiotics on carcass percentage, normal abdominal weight and internal organs in broilers. J. Sains Teknol. Indonesia,12:53-59.https://doi.org/10.29122/ jsti.v12i1.851

Afzal, M. and M. Khan. 2017. Economic analysis of broiler poultry farms: A case study of District Lower Dir. Sarhad J. Agric., 33: 183-188. https://doi.org/10.17582/journal. sja/2017.33.1.183.188

Choe, J.H., K. Nam, S. Jung, B. Kim, H. Yun and C. Jo. 2010. Differences in the quality characteristics between commercial Korean native chickens and broilers. Korean J. Food Sci. Anim. Resour., 30: 13-19. https://doi. org/10.5851/kosfa.2010.30.1.13

Chukwuji, C.O., O.E. Inoni, O.D. Ogisi and W.J. Oyaide. 2006. A quantitative determination of allocative efficiency in broiler production in Delta State, Nigeria. Agric. Conspec. Sci., 71: 21-26.

Daneshyar, M., M.A. Ghandkanlo, F.S. Bayeghra, F. Farhangpajhoh and M. Aghaei. 2011. Effects of dietary turmeric supplementation on plasma lipoproteins, meat quality, and fatty acid composition in broilers. S. Afr. J. Anim. Sci., 41: 420-428. https://doi.org/10.4314/sajas. v41i4.13

Dermawaty, D.E., 2015. Potential extract curcuma (Curcuma xanthorriza Roxb.) as anti bacterials. J. Majority, 4: 5-11.

Devaraj,S.,A.Esfahani,S.Ismail and S.R.Molecules. 2010. Evaluation of the antinociceptive activity and acute oral toxicity of standardized ethanolic extract of the rhizome of Curcuma xanthorrbiza Roxb. Molecules, 15: 2925-2934. https://doi. org/10.3390/molecules 15042925 
Emadi, M. and H. Kermanshahi. 2007. Effect of turmeric rhizome powder on immunity responses of broiler chickens. J. Anim. Vet. Adv., 6: 833-836. https://doi.org/10.3923/ ijps.2007.345.348

Ghalandarlaki, N., A.M. Alizadeh and S. AshkaniEsfahani. 2014. Nanotechnology-applied curcumin for different diseases therapy. Biomed Res. Int., 2014: 394264. https://doi. org/10.1155/2014/394264

Golla, Y., M.E.R. Montong, J.T. Laihaddan and G.D.G. Rembet. 2014. The effectiveness of the addition of Curcuma xanthorriza Roxb. powder and Curcuma zedoria Rosc. powder in commercial rations on carcass percentage, amdominal fat, and the percentage on liver in boiler. Zootek J., 34: 115-123. https://doi. org/10.35792/zot.34.0.2014.4800

Jantan, I., F.C. Saputri, M.N. Qaisar and F. Buang. 2012. Correlation between the chemical composition of Curcuma domestica and Curcuma xanthorrhiza and their antioxidant effect on human low-density lipoprotein oxidation. Evid. Based Complem. Altern. Med., 2012: 438356. https://doi.org/10.1155/2012/438356

Kalamkar, S.S. 2012. Inputs and services delivery system under contract farming: A case of broiler farming. Agric. Econ. Res. Rev., 25: 515-521.

Lee, L.Y., J.S. Shim, Y. Rukayadi and J.K. Hwang. 2008. Antibacterial activity of xanthorrhizol isolated from Curcuma xanthorrbiza Roxb. against foodborne pathogens. J. Food Protect., 71: 1926-1930. https://doi.org/10.4315/0362028X-71.9.1926

Patzko, A., I.Y. Bai, M.A, Saporta, I. Katona, X.Y. Wu, D. Vizzuso, M.L. Feltri, S. Wang, L.M. Dillon, J. Kamholz, D. Kirschner, F.H. Sarkar, L. Wrabetz and M.E. Shy. 2012. Curcumin derivatives promote Schwann cell differentiation and improve neuropathy in R98C CMT1B mice. Brain, 135: 3551-3566. https://doi.org/10.1093/brain/aws299

Rahayu, I.D., W. Widodo, I. Prihartini, A. Winaya, L. Zalizar, T. Untari and M. Mel. 2019a. The potential of an extract of Zingiber zerumbet (L.) Smith as a feed additive to improve the production performances and meat nutritional composition of broiler chickens. IOP Conf. Ser. Eaeth Environ. Sci., 293: 012023. https://doi. org/10.1088/1755-1315/293/1/012023

Rahayu, I.D., W. Widodo, I. Prihartini and A.
Winaya. 2019b. Antibacterial activity of ethanolic extracts from Zingiber zerumbet rhizome against Salmonella spp. Biodiversitas, 20: 3322-3327. https://doi.org/10.13057/ biodiv/d201127

Rahim, N., P. Hassandarvish, S. Golbabapour, S. Ismail, S. Tayyab and M.A. Abdulla. 2014. Gastroprotective effect of ethanolic extract of Curcuma xanthorrbiza leaf against ethanolinduced gastric mucosal lesions in SpragueDawley rats. Biomed Res. Int., 2014: 416409. https://doi.org/10.1155/2014/416409

Saili, T., R. Aka, F.A. Auza, W.L. Salido, A.M. Sari and A. Napirah. 2019. Production performance of local village chicken fed by agriculture by-product supplemented with herbal probiotics and mud clams extract (Polymesoda erosa) in Kendari-South-East Sulawesi. J. Peternak. Indones., 21: 327-336. https://doi. org/10.25077/jpi.21.3.327-336.2019

Salas, C., R.D. Ekmay, J. England, S. Cerrate and C.N. Coon. 2012. Determination of chicken body composition measured by dual-energy x-ray absorptiometry. Int.J. Poult. Sci., 11: 462468. https://doi.org/10.3923/ijps.2012.462.468

Samadi, M. Delima and Herawati. 2019. Effect of various feed additives administration on performance and hematological parameters of local chickens (Gallus domesticus). IOP Conf. Ser. Earth Environ. Sci., 260: 012065. https:// doi.org/10.1088/1755-1315/260/1/012065

Sinurat, A.P., T. Purwadaria, I.A.K. Bintang, P.P. Ketaren, N. Bermawie, M. Raharjo and M. Rizal. 2009. The utilization of turmeric and curcuma as feed additive for broilers. J. Ilmu Ternak Vet., 14: 90-96.

Stoilova, I., A. Krastanov, A. Stoyanova, P. Denev and S. Gargova. 2007. Antioxidant activity of a ginger extract (Zingiber officinale). Food Chem., 102: 764-770. https://doi.org/10.1016/j. foodchem.2006.06.023

Sugiharto, Isroli, E. Widiastuti and N.S. Prabowo. 2017. Effect of turmeric extract on blood parameters, feed efficiency, and abdominal fat content in broilers. J. Indonesian Trop. Anim. Agric., 36: 21-26. https://doi.org/10.14710/ jitaa.36.1.21-26

Suriya, R., I. Zulkifli and A.R. Alimon. 2012. The effect of dietary inclusion of herbs as a growth promoter in broiler chickens. J. Anim. Vet. Adv., 11: 346-350. https://doi.org/10.3923/ 
javaa.2012.346.350

Widodo, W. 2014. Nutrition of poultry. UMM Press, Malang, Indonesia.

Widodo, W., A. Sutanto and I.D. Rahayu. 2018. Addition of “jamu lempuyang" (Zingiber zerumbet herbs) in feed toward the condition of the nutrition digestibility of kampong chicken. Proc. Adv. Social Sci. Edu. Humanit. Res., 231: 505-508. https://doi.org/10.2991/amca18.2018.140

Widodo, W., I.D. Rahayu, A. Sutanto, R.H.
Setyobudi and M. Mel. 2019. The effectiveness of curcuma (Curcuma xanthorriza Roxb.) addition in the feed toward super kampong chicken performances. Proc. Pakistan Acad. Sci. Part B, 56: 39-46.

Yu,W.,J.Wu,F.Cai,J.Xiang,W.Zha,D.Fan,S.Guo, Z. Ming and C. Liu. 2012. Curcumin alleviates diabetic cardiomyopathy in experimental diabetic rats. PLoS One, 7: e52013. https://doi. org/10.1371/journal.pone.0052013 